\title{
FORMASI NALAR FIKIH ISLAM PESISIR KIAI SALEH DARAT
}

\author{
Dr. Nurul Huda, M.HI \\ Institut Agama Islam (IAI) Sunan Giri Bojonegoro \\ Email: abzaryal@gmail.com
}

\begin{abstract}
Abstrak: Formasi nalar fikih Kiai Saleh Darat mengambil corak nalar fikih Islam pesisir bayani cum irfani yang bersifat, pertama, dialektis; konstruksi nalar yang mengakui perlunya dialektika antara tradisi Arab dan tradisi lokal sebagai sebuah entitas yang saling menggeluti pemaknaan hidup, sehingga melahirkan tradisi baru. Kedua, SemiPartikularistik; nalar yang tidak mengakui elemen-elemen bersifat normatif secara mutlak untuk segala masyarakat yang mau melangsungkan Islamisasi. Ketiga, SemiPluralistik; konstruksi nalar yang tidak menyetujui asas tunggal dan abadi secara mutlak sehingga berpotensi menghakimi dan menghilangkan pluralitas budaya lokal yang bersifat incommensurable.
\end{abstract}

Kata kunci: Nalar Fikih, Islam Pesisir

\section{A. PENDAHULUAN}

Islam dan budaya memang tidak dapat dipisahkan dikarenakan keduanya lahir sebagai fenomena sosial. Sebagai sebuah produk sosial, Islam senantiasa terikat dengan unsur lokalitas kultur yang bersifat partikular dan relatif. ${ }^{1}$ Hubungan kehendak Allah dan kebudayaan manusia bersifat dialektis. ${ }^{2}$ Sebagai produk dialektis, sangat wajar jika sebagian Ulama menghendaki agar dimensi partikular yang ada dalam Islam dibedakan dari dimensi universalitasnya. Episteme inilah yang kemudian melahirkan diskursus normativitas dan hostorisitas dalam Islam. Wajar apabila Islam sebagai risalah terakhir mempunyai dua watak (karakter) ganda. Artinya, pada satu sisi Islam berwatak abadi (tsawābit) yang sakral sebagai wahyu Tuhan. ${ }^{3}$ Namun pada sisi lain, Islam juga berwatak profan (mutaghayyirāt) dinamis dengan perubahan ruang dan waktu. Islam watak kedua lebih didasarkan kreasi manusia (ijtihād) dalam merespon dinamika kehidupan manusia hukum Islam selalu membumi dan mampu merespon segala perubahan. ${ }^{4}$

Transformasi keilmuan Islam di daerah pesisir utara yang dilakukan pedagang sejatinya bersifat dinamis, sedangkan di daerah pedalaman, transformasi keilmuan bersandar

\footnotetext{
${ }^{1}$ Muhammad Arkoun, al-Fikru al-Ushuly wa Istihalat at-Ta'sil Nahwa Tarikhin Akhar li al-Fikr alIslamy, (London: Dar as-Saqi, 1999) hal. 115.

2 M. Amin Abdullah, "Rekonstruksi Metodologi Studi Agama dalam Masyarakat Multikultural dan Multirelijius" dalam M. Amin Abdullah, dkk (editor), Antologi Studi Islam; Teori dan Metodologi (Yogyakarta: Sunan Kalijaga Press, 2000), hal. 6-7.

${ }^{3}$ Noel J. Coulson, Conflicts and Tensions in Islamic Jurisprudence (Chicago: The University of Chicago Press, 1969), hal. 3;

${ }^{4}$ Yusuf al-Qarâdhawî, al-Madkhal li Dirâsah al-Syarî’ah (Kairo: Maktabah Wahbah, 2001), hal. 22; lihat juga dalam Iskandar Usman, Istihsan dan Pembaruan Hukum Islam, (Jakarta: Rajawali Pers dan Lembaga Studi Islam dan Kemasyarakatan, 1994), hal. 103-104.
} 


\section{Dr. Nurul Huda, M.HI}

pada petani yang statis. Islam turun dari budaya kosmopolitan menjadi budaya lokal yang kehilangan karakter universalitasnya. ${ }^{5}$

Kondisi lingkungan dan pekerjaan masyarakat petani, mempengaruhi cara berfikir dari historis realistis menjadi bersifat mitos. Pada saat yang sama, pemahaman keilmuan Islam mereka masih diwarnai pemahaman keagamaan lama, yaitu Hindu Budha, sehingga melalui karakter keilmuan Islam demikian ini, menyulitkan masyarakat Jawa pedalaman Jawa Tengah menerima keilmuan Islam dalam waktu cepat. ${ }^{6}$

Artinya vitalitas keilmuan Islam dari pesisir utara meredup, karena karakter tradisi besar hanya sedikit saja jumlahnya pada golongan atas, sedangkan kelompok massa yang lebih besar jumlahnya berkarakter tradisi kecil. ${ }^{7}$

Lembaga pendidikan Islam di pesisir Jawa menindak lanjuti dengan pengajaran keilmuan yang bersumber dari Al-Qur'an, Hadis, dan ilmu keislaman, seperti ushul, fiqh, dan tasawuf yang ditulis oleh para ulama salaf dalam kitab-kitab klasik. ${ }^{8}$ Jenis keilmuan yang diajarkan para ulama menunjukkan bahwa semenjak abad ke-15 keilmuan Islam yang bercorak ortodoks legalistik atau fiqh ${ }^{9}$ dan tasawuf telah diajarkan dan diamalkan secara bersama-sama oleh masyarakat pesisir utara Jawa. ${ }^{10}$

Akibat pengajaran yang bercorak ortodoks legalistik atau fiqh dan doktrin mistik ortodoks, maka pada sekitar abad ke-17 karya mistik heterodoks hampir tidak muncul lagi dalam sastra keagamaan di wilayah pesisir utara Jawa Tengah. ${ }^{11}$

Para ulama menyampaikan ajaran Islam agar masyarakat great tradition bisa melaksanakan secara taat pada masa awal. Namun para ulama cukup toleran terhadap masyarakat little tradition dengan mengajarkan bentuk luar kepercayaan yang masih bercampur dengan kepercayaan dan kebiasaan lokal.

Masyarakat little tradition diusahakan sedapat mungkin mampu menjalankan praktik agama secara benar. Mereka tetap menempatkan ajaran Islam dalam bentuk konsep asli dan

\footnotetext{
${ }^{5}$ Anthony Reid, Sejarah Modern Awal Asia Tenggara (Jakarta: LP3ES, 2004), hal.8

${ }^{6}$ Martin, Van Bruinessen, Kitab Kuning, Pesantren dan Tarekat (Bandung: Penerbit Mizan, 1995), hal. 28

${ }^{7}$ Niels Mulder, Agama, Hidup Sehari-hari dan Perubahan Budaya Jawa, Muang Thai dan Filipina (Jakarta: Gramedia Pustaka Utama, 1999), hal. 312

${ }^{8}$ Hanun Asrohah, Pelembagaan Pesantren, Asal-usul dan Pelembagaan Pesantren di Jawa, Disertasi, (Jakarta: UIN Syarif Hidayatullah, 2002), hal. 90.

${ }^{9}$ Martin, Van Bruinessen, Kitab Kuning, Pesantren dan Tarekat (Bandung: Penerbit Mizan, 1995), hal. 28

${ }^{10}$ Pigeaud, Th. G. Th., Literature of Java, Descriptive List of Javanese Manuscript (Leiden: Bibliotica Universiti Leiden, 1967), hal. 78.

${ }^{11}$ De Graaf and Pigeaud, Kerajaan-kerajaan Islam di Jawa (Jakarta: Grafiti Pers, 1987), hal. 52, 78.
} 
tidak diolah dalam bentuk fusi atau sinkretisasi. Para pengajar membiarkan sementara kepercayaan teosentris Islam diterima lebih dahulu, tanpa menghilangkan kepercayaan lama.

Dalam taraf ini ada dualisme kepercayaan, Islam dan Islam dengan kepercayaan lokal yang seiring, tapi bukan sintesa. Karena kepercayaan Islam tidak memungkinkan terjadinya sintesa dengan kepercayaan lokal. ${ }^{12}$

Maka, menurut Ismawati, penyebar keilmuan Islam di pesisir utara Jawa Tengah pada abad ke-15 sampai dengan ke-17 telah berhasil memperlihatkan karakter legalistik dan menghindarkan masyarakat dari keilmuan mistisisme yang menyesatkan. Namun kelambanan penyiaran keilmuan Islam di daerah pedalaman Jawa Tengah mengakibatkan ketidaksetaraan tingkat pemahaman dan sebagai akibat dari pengaruh ajaran Syaikh Siti Jenar dan pengaruh Hindu yang lama berakar pada masyarakat Jawa.

Maka keilmuan Islam di sini berkarakter sinkretisme, berfokus kepada mistisisme heterodoks. Keilmuan ini pada masa berikutnya dikenal sebagai Ilmu Islam Kejawen. ${ }^{13}$ Karakter sinkretis menjadi ciri menonjol dalam keilmuan Islam di Jawa pedalaman terutama setelah era kekuasaan pemerintahan berpusat di Pajang, kemudian dilanjutkan Mataram dan sampai akhirnya kekuasaan berpindah ke Kartasura. Di samping juga karena pengaruh ajaran Hindu sebelumnya serta keilmuan yang bersumber dari para pujangga dan para bangsawan keraton Jawa. Serat-serat keraton tersebut sempat memberi warna keilmuan Islam bagi masyarakat Jawa Tengah yang telah lama menerima pengaruh Hindu-Buddha. ${ }^{14}$

Dari uraian di atas, perlu kajian yang serius, apakah pengetahuan Islam pesisir pada abad ke-19 ditransformasikan sesuai dengan karakter aslinya atau justru Islam Pesisir tenggelam dalam transformasi pengetahuan Islam sinkretik dan kejawen? Padahal menurut penelitian Nur Syam, pada abad ke-20, Islam pesisir yang sering ditipologikan sebagai Islam murni yang bersentuhan pertama kali dengan tradisi besar Islam ternyata adalah Islam yang kolaboratif, yaitu corak hubungan antara Islam dengan budaya lokal yang bercorak inkulturatif sebagai hasil konstruksi bersama antara agen (elit-elit lokal) dengan masyarakat dalam sebuah proses dialektika yang terjadi secara terus menerus.

Ciri-ciri Islam kolaboratif adalah bangunan Islam yang bercorak khas, mengadopsi unsur lokal yang tidak bertentangan dengan Islam dan menguatkan ajaran islam melalui

12 Abdul Munir Mulkhan, Ajaran dan Jalan Kematian Syaikh Siti Jenar (Yogyakarta: Kreasi Wacana, 2003), hal. 114

${ }^{13}$ Ismawati, "Karakter Keilmuan Islam Di Pesisir Utara Dan Pedalaman Jawa Tengah, Nusantara Abad Ke 15-17”, dalam Teologia, Volume 23, Nomor 1, Januari 2012, hal. 230.

${ }^{14}$ Ibid., hal.229. 
proses transformasi secara terus menerus dengan melegitimasinya berdasarkan atas teks-teks Islam yang dipahami atas dasar interpretasi elit-elit lokal. ${ }^{15}$

Secara ontologis, penelitian ini menggunakan teori hermeneutika Hans-Georg Gadamer yang bertumpu pada empat asumsi dasar. Pertama, kesadaran keterpengaruhan oleh sejarah; orang yang menafsirkan syari'ah dipengaruhi oleh tradisi, kultur, dan pengalaman hidup yang melingkupinya.

Kedua, pra-pemahaman; penafsir agama tidak dapat dipisahkan dari prapemahaman yang dimilikinya. Ketiga, penggabungan atau asimilasi horizon. Di sini selanjutnya penafsir mengkomunikasikan horizon dirinya dengan horizon teks.

Keempat, penerapan atau aplikasi. Dengan hasil penggabungan horizon tersebut akan memunculkan makna obyektif yang harus dipraktikkan dalam kehidupan sehari-hari. ${ }^{16}$

\section{B. PEMBAHASAN}

Secara bahasa fiqh merupakan bentuk mashdar dari kata faqiha-yafqahu-fiqhan yang oleh Abu Zahrah diartikan ungkapan: "pemahaman yang mendalam dan akurat sehingga dapat dipahami (dengan baik) tujuan ucapan dan atau tindakan (tertentu)". ${ }^{17}$

Secara bahasa fiqh berarti paham atau mengerti. Ilustrasi terkait arti fiqh dikemukakan oleh Ibn Manzhur al-Ansari, dalam karyanya Lisān al-'Arab ia mengutip doa Nabi Muhammad untuk Ibnu Abbas, "Tuhanku, ajarilah ia agama dan jadikanlah ia mengerti tafsirnya”. Dalam penjelasannya, al-Anshari menjelaskan bahwa pengertian fiqh dalam hadits tersebut paham terhadap tafsir dan maknanya. ${ }^{18}$

Sedangkan arti fiqh secara terminologi para ulama berbeda secara redaksional, namun secara substantif mempunyai makna yang sama. Yusuf al-Qaradlawi misalnya, mendefinisikan fiqh adalah pengetahuan tentang hukum-hukum syarī'ahyang bersifat praktis yang digali dari dalil-dalil yang rinci. ${ }^{19}$ al-Jurjani, dalam al-Ta'rîfāt, mengartikan fiqh sebagai ilmu yang digali melalui penalaran ijtihad..$^{20}$

\footnotetext{
${ }^{15}$ Nur Syam, Islam Pesisir (Jogyakarta: LKIS, 2005)

${ }^{16}$ Sahiron Syamsuddin, Upaya Integrasi Hermeneutika dalam Kajian Qur'an dan Hadis, (Yogyakarta: Lembaga Penelitian UIN SUKA, 2011) hal. 36-40

${ }^{17}$ Muhammad Abu Zahrah, Ushul al-Fiqh (Kairo: Dar al-Fikr al-'Arabi, 1987), hal. 4.

${ }^{18}$ Ibn Mandhur al-Anshari, Lisan al-Arab, Jilid XIII (Beirut: Dar al-Fikr, t.th.), hal. 522

${ }^{19}$ Yusuf al-Qaradlawu, Madkhal li Dirasah al-Syari'ah al-Islamiyyah (Kairo: Maktabah Wahbah, 2001), hal. 21.

${ }^{20}$ Abi al-Hasan al-Husaini al-Jurjani, al-Ta 'rifāt, (Mesir: Musthafa al-Babi al-Halabi, 1938) hal. 147.
} 
Amir Syarifuddin mengemukakan fiqh adalah ilmu tentang hukum-hukum syara' yang bersifat amaliah yang digali dan ditemukan dari dalil-dalil yang tafsili. ${ }^{21}$ Sedangkan dalam perspektif A. Qodri Abdillah Azizi, fiqh berarti "paham" (understanding) yang menjadi kebalikan dari --dan sekaligus melengkapi-- kata “'ilm" (menerima pelajaran) terhadap materi Al-Qur'an dan Sunnah.

Penerimaan ini tanpa melalui pemikiran dan upaya pemahaman, melainkan melalui riwayat. Dengan demikian 'ilm berbeda dengan figh yang harus memberi status sebuah hukum terhadap suatu masalah dengan cara menafsirkan Al-Qur'an dan Sunnah. ${ }^{22}$

Berbasis pada beberapa pengertian yang lahir terkait pemaknaan figh dapat diambil pemahaman besar bahwa fiqh sangat identik dengan kerja akal manusia dalam memahami, menggali, menafsiri sumber utama.

Sebagai produk manusia tentunya fiqh mempunyai dimensi yang profan. Sementara Asaf A.A Fyzee mencoba memperjelas ruang lingkup fiqh lebih sempit, hanya menyangkut hal-hal yang pada umumnya dipahami sebagai aturan-aturan hukum yang bertumpu pada kemampuan penalaran. ${ }^{23}$

Nasaruddin Umar juga mengemukakan bahwa fiqh adalah ajaran non-dasar, bersifat lokal, elastis dan tidak permanen. Selain itu, fiqh sejatinya merupakan penafsiran kultural terhadap syari'ah yang dikembangkan oleh ulama'/fuqaha' fiqh (yuristik) semenjak abad ke-2 $\mathrm{H} / 9 \mathrm{M}^{24}$

Sedangkan dinamika dan gerakan pembaruan hukum Islam, tidak bisa dilepaskan dari pengaruh pluralitas sosial-budaya, politik dalam suatu masyarakat dan negara. Para ulamā/fuqāhā' seringkali menafsirkan teks-teks Al-Qur'an dan Sunnah dalam konteks sosialbudaya dan politik. ${ }^{25}$

Fakta sejarah menunjukkan pada masa Islam yang begitu awal, telah lahir berbagai madzhab fiqh, ada madzhab Hijaz, madzhab Irak dan Siria. ${ }^{26}$ Kendati demikian, rumusan

${ }^{21}$ Amir Syarifuddin, Pembaruan Pemikiran dalam Hukum Islam, (Padang: Angkasa Raya, 1990) hal. $14-15$.

${ }^{22}$ A. Qodri A. Azizy, Eklektisisme Hukum Nasional: Kompetisi antara Hukum Islam dan Hukum Umum (Yogyakarta: Gama Media, 2002) hal. 2-3.

23 Asaf A.A. Fyzee, Outlines of Muhammadan Law (London: Oxford, 1960) hal. 21.

${ }^{24}$ Nasaruddin Umar, Argumen Keseteraan Jender: Perspektif Alquran (Jakarta: Paramadina, 1999) hal. 290.

${ }^{25}$ A. Qodri A. Azizy, Eklektisisme Hukum Nasional; Kompetisi Antara Hukum Islam dan Hukum Umum, (Yogyakarta: Gama Media, 2002), hal. 32-33

${ }^{26}$ Abd al-Wahhab Ibrahim Abi Sulaiman, al-Fikru al-Ushuli; Dirasah Tahliliyyah Naqdiyyah, (Jeddah: Dar al-Syuruq, Cet. I, 1983) hal. 44-46 
teori hukum Islam baru ditemukan pada abad ke-2 H, oleh al-Syafi'i dengan karyanya alRisālah. $^{27}$

Selanjutnya, gagasan pembaruan hukum Islam diteruskan oleh al-Ghazali (w.505/1111) dengan membangun teori mașlahah, dan kemudian dilanjutkan oleh al-Syāthibî (790/1138). Dan, pada awal fase modern muncul Muhammad Abduh (w.1905) dengan rekonstruksi rasionalisme klasik. ${ }^{28}$

Secara umum, pola pembaruan hukum Islam, telah terbagi menjadi dua kelompok: pertama, kelompok ahli hukum Islam (fuqāhā/mujtahid) yang dikategorikan dengan aliran "tekstual-teosentris".

Kelompok ini selalu menjadikan teks-teks Al-Qur'an dan Sunnah sebagai pijakan utama dalam justifikasi aktivitas mereka. Artinya, teks-teks yang jelas dan rinci dalam bidang hukum Islam yang terdapat dalam Al-Qur'an dan Sunnah dan kitab-kitab karya ahli fiqh tradisional harus diterima apa adanya tanpa membutuhkan tafsir ulang. ${ }^{29}$

Kedua, kelompok ahli hukum yang diidentikkan dengan orang legal theorists. Yakni kelompok yang berpandangan bahwa agar hukum Islam selalu mampu menjawab tantangan zaman dan tak kehilangan elan vitalnya, maka pintu ijtihad harus dibuka selebar-lebarnya. Mereka ini sering diidentikkan dengan kelompok yang mengedepankan peran akal dan memberikan porsi utama dalam menjawab realitas dan perubahan sosial. ${ }^{30}$

Selanjutnya, salah satu nalar yang diajukan Al-Jabiri adalah Nalar bayani, ${ }^{31}$ merupakan epistemologi yang mencakup disiplin-disiplin ilmu yang berpangkal dari bahasa Arab seperti: nahwu, fiqh, ushul al-fiqh, kalam, dan balaghah. ${ }^{32}$ Menurut al-Jabiri, wacana bayani yang berkembang dalam sejarah Islam, secara substansial, terfokus pada dua domain, yaitu kaidah-

${ }^{27}$ Terkait siapa sejatinya penemu ilmu ushul al-fiqh masih menjadi perdebatan. Secara praktis praktikpraktik hukum berbasis pembaruan telah ada sebelum Asy-Syafi'i. Tidak mengherankan jika dari kalangan Ahnaf, mengklaim bahwa Abu Hanifah, Syaibani dan Abu Yusuf adalah tokoh-tokoh peletak ilmu ushul al-fiqh. Dapat dikatakan pada era mereka memang telah terbentuk metodologi hukum Islam, namun masih membaur dengan kajian-kajian lainnya, semisal fiqh dan sebagainya. Baru pada era al-Syafi'i, beliaulah yang menyusun ilmu usul al-fiqh secara sistematis dan terpisah dari ilmu-ilmu lainnya. Detainya lihat karya Abd al-Wahhab Ibrahim Abi Sulaiman, op. cit. hal. 5-6.

${ }^{28}$ Syamsul Anwar, "Pengembangan Metode Penelitian Hukum Islam" dalam Ainurrofiq (ed.), Mazhab Jogja”; Menggagas Paradigma Ushul Fiqh Kontemporer (Yogyakarta: Ar-Ruzz Press dan Fakultas Syariah IAIN Sunan Kalijaga, 2002) hal. 148-149.

${ }_{29}$ Satria Effendi M, "Ijtihad Sepanjang Sejarah Hukum Islam: Memposisikan KH Ali Yafie" dalam Jamal D. Rahman (ed.) Wacana Baru Fiqh Sosial; 70 Tahun KH Ali Yafie (Bandung: Mizan, 1997), hal. 154155.

${ }^{30}$ Ibid., hal. 154 .

${ }^{31}$ Bayani secara bahasa bahasa mempunyai lima makna, yaitu: (a) al-waslu/sampai (2) al-fashl/sampai (3) al-zhuhur wa al-wudluh/tampak dan jelas (4) al-fasahah wa al-qudrah 'ala al-tabligh/sehat dan mampu menyampaikan dan menenangkan (5) al-insan hayawan mubin/manusia hewan berlogika.

${ }^{32}$ M. Amin Abdullah, "al-Ta’wil al-'Ilmi: Ke Arah Paradigma Penafsiran Kitab Suci” dalam Jurnal alJami'ah Vol. 39, Number 2 July-December 2001, hal. 371. 
kaidah interpretasi wacana, seperti “dasar-dasar penafsiran ayat-ayat Al-Qur'an”, yang fondasi telah dibangun semenjak era Nabi dan para sahabat dan "syarat-syarat produksi wacana".

Domain yang kedua ini belakangan muncul karena terjadinya diaspora dan polarisasi kaum muslimin ke dalam berbagai aliran teologi maupun politik. Domain pertama masih menunjukkan keterikatan kuat dengan teks, seperti halnya pendekatan konservatif dalam tafsir, sedangkan pada domain kedua, teks telah masuk kepada persoalan logika, yakni bagaimana melahirkan wacana. ${ }^{33}$

Perkembangan epistemologi bayani ini semakin diperkuat oleh al-Syafi'i dengan meletakkan aturan-aturan penafsiran dalam bentuk yang baku. Sumbangan al-Syafi'i sangat penting dalam nalar bayani, terutama berkaitan dengan gagasannya yang memposisikan alSunnah sebagi nash kedua.

Nash al-Sunnah berfungsi sebagai penetap (pencipta) hukum, perluasan cakupan alsunnah yang dengan tidak secara tegas membedakan antara "sunnah-tradisi" dan "sunnahwahyu" serta pembatasan ruang gerak ijtihad dengan nash-nash baik Al-Qur'an maupun Sunnah. ${ }^{34}$

Diakui, al-Syafi'i telah berhasil membangun kuat fondasi dalam cara-cara berpikir yang menyangkut hubungan antara bahasa dengan teks Al-Qur'an serta hubungan antara lafāzh dengan makna. Ia kemudian menjadikan Al-Qur'an, Sunnah, Ijma', dan Qiyas sebagai sumber pengetahuan yang valid dalam menjawab dinamika persoalan umat manusia.

Dalam perspektif al-Syafi'i, berpikir harus dalam koridor teks-teks keagamaan. Dalam tradisi nalar bayani hanya ada dua dimensi fundamental yaitu yang pokok (ushūl) atau prinsip-prinsip primer dan yang sekunder ( $\left.f u r \bar{u}^{\prime}\right)$ yang keduanya dikembangkan dalam prinsip-prinsip fundamental tersebut. ${ }^{35}$

Epistemologi bayani dalam perjalanan sejarahnya, dikembangkan oleh pemikir-pemikir berikutnya dengan tidak lagi sebatas pada kerja "memahami" melainkan bagaimana mampu membuat pendengar paham dan menuntaskan perdebatan. Bahkan, nalar ini oleh Ibn Wahhab dikembangkan menjadi sebuah metode dan sistem untuk memperoleh pengetahuan. ${ }^{36}$

${ }^{33}$ Muhammad Abid al-Jabiri, Formasi Nalar Arab; Kritik Tradisi Menuju Pembebasan dan Pluralisme Wacana Interreligius, terj. Imam Khoiri (Yogyakarta: IRCiCoD, 2003) hal. 157-217.

${ }^{34}$ Muhammad Abid al-Jabiri, Bunyat al-'Aql al-'Araby: Dirasah Tahliliyah Naqdiyah li Nuzhumi alMa'rifah fi al-Tsaqafah al- 'Arabiyah (Beirut: Markaz Dirasat al-Wihdat al-'Arabiyah, Cet. Ke-3, 1990), hal. 22, lalu bandingkan dengan Nashr Hamid Abu Zaid, al-Tafkir fi Zamani al-Tafkir, (Kairo: Sina’ li al-Nasyr, 1995), hal. 149.

${ }^{35}$ Muhammad Abid al-Jabiri, Post-Tradisionalisme Islam, terj. Ahmad Baso (Yogyakarta: LkiS, 2000) hal. xi-xii.

${ }^{36}$ Muhammad Abid al-Jabiri, Bunyat al- 'Aql al- 'Araby...op. cit., hal. 38. 
Lebih lanjut, menurut al-Jabiri, pada nalar (epistemologi) bayani ini terdapat beberapa watak dasar yang dapat dijadikan landasan operasionalnya, yaitu pasangan: al-lafazh-alma'na, al-ashlu-al-far'u dan al-khabar-al-qiyas. Di sisi lain, Menurut Sari Nusibeh, salah satu peta pemikiran Islam menggunakan pendekatan konservatif.

Dalam model ini ada dua tipe teori tentang kebenaran: (a) kebenaran melalui teks-teks wahyu; dan (b) kebenaran melalui logika terhadap teks tersebut. Teori kebenaran pertama merupakan kebenaran mutlak karena berangkat dari pandangan bahwa kebenaran-kebenaran yang tak terjangkau yang hanya menjadi domain keyakinan.

Sedang kebenaran kedua hanya bersifat komplementer. Dari teori kebenaran kedua ini lahirlah ilmu-ilmu yang ditransmisikan semisal ilmu-ilmu: fiqh, tafsir, ilmu tafsir, ushül alfiqh dan ilmu-ilmu lainnya. ${ }^{37}$

Epistemologi irfani dalam bahasa Inggris sama dengan kata gnose atau gnosis dan derivasi dari fi' il madhi 'arafa yang berubah menjadi isim masdar menjadi 'irfan yang berarti pengetahuan, al-hikmah atau al-'ilm.

Dalam perjalanannya, istilah ini identik atau sering digunakan dalam terminologi mistik yang berarti ma'rifah yang berarti pengetahuan tentang Tuhan. Pengetahuan eksoterik merupakan pengetahuan yang diperoleh dari nalar empirikal dan rasional melalui istidlāl, sementara 'irfāni merupakan pengetahuan esoterik yang diperoleh melalui qalb atau kasyf, ilhām dan 'iyān (persepsi langsung). ${ }^{38}$

Epistemologi irfani banyak didukung oleh para sufi. Salah satu tokoh tasawuf Dzu alNun al-Misri (w.245 H) berpendapat bahwa pengetahuan dibagi menjadi tiga bagian: (a) pengetahuan tauhid yang spesifik dimiliki orang-orang mukmin yang ikhlas.

(b) pengetahuan al-hujjah wa al-bayān (argumen dan logika) yang khusus dimiliki oleh ahli hukum, ahli bahasa dan ulama yang ikhlas. (c) pengetahuan sifat al-wahahdāniyāt (sifatsifat keesaan) yang hanya dimiliki oleh wali-wali Allah yang ikhlas yang menyaksikan Allah dengan hati (qalbu) mereka, sehingga tampak kebenaran bagi mereka, namun tidak mampu dilihat oleh orang-orang awam. ${ }^{39}$

Para ilmuwan pendukung nalar irfani ini memandang bahwa pengetahuan tentang Tuhan (hakikat Tuhan) tidak dapat diketahui melalui bukti-bukti empiris-rasional, melainkan harus melalui pengalaman langsung.

37 Sari Nusibeh, "Epistemology" dalam Oliver Leaman dan Sayyed Hossein Nasr (ed.), History of Islamic Philoshopy Part II ( London and New York: Routledge, 1996) hal. 826-840.

${ }^{38}$ Muhammad Abid al-Jabiri, Bunyat al- 'Aql al- 'Araby...op. cit., hal. 253.

${ }^{39}$ Ibid., hal. 251. 
Agar dapat berhubungan langsung dengan Tuhan, seseorang harus mampu melepaskan diri dari segala ikatan dengan alam yang merintanginya. Dalam konsep irfani, Tuhan merupakan realitas yang berbeda dan tidak berkaitan sama sekali dengan alam.

Sedangkan indera, akal merupakan bagian dari alam sehingga tidak mungkin mengetahui Tuhan tersebut. Dengan demikian, satu-satunya instrumen untuk sampai pada pengetahuan Tuhan adalah jalan nafs. Sebab nafs merupakan manifestasi Tuhan di alam yang pada akhirnya juga akan kembali kepada-Nya pada saat ia telah terbebas dari hubungannya dengan alam dan bersih dari segala dosa. ${ }^{40}$

Berbeda dengan karakteristik nalar bayani yang telah diurai di atas, dalam nalar irfani terdapat istilah atau konsep yang lazim dikenal dalam tradisi nalar ini. Diantaranya adalah zhāhir-bāthin dengan menjadikan zhāhir teks sebagai batin.

Para pengguna nalar irfani menjelaskan bahwa yang zhāhir adalah bacaan (tilāwah)nya sedangkan yang batin adalah ta'wil-nya. Ta'wil di sini dimaknai sebagai transformasi ungkapan zhāhir ke batin dengan berpegangan pada isyarat (petunjuk batin). ${ }^{41}$

Selain konsep zhāhir-bāthin, dalam nalar irfani juga mengenal konsep al-wilāyah-alnubuwwah, yakni al-wilayah sebagai representasi dari yang batin dan al-nubuwwah sebagai representasi dari yang lahir.

Al-wilayah di sini adalah subjek yang dimaknai sebagai otoritas dan hirarki spiritual dari guru terus ke gurunya sampai pada syeikh yang paling tinggi. ${ }^{42}$ Menurut Sari Nusibeh, epistemologi Islam adalah pendekatan mistis.

Dalam pendekatan ini seseorang lebih menekankan aspek pengalaman pribadi yang bersifat intuitif. Pendekatan ini mampu menghasilkan al-'ilmu $\underline{h} u d h \bar{u} r i$, yakni pengetahuan diri yang bersifat presensial.

Hal ini berangkat dari postulat bahwa pengalaman intuitif akan menyerap secara holistik objek pengetahuan yang dengan pendekatan lain hanya bisa diserap secara fragmental. ${ }^{43}$

Adapun situasi masyarakat yang mobile dan nomadik, menurut Abid al-Jabiri, satusatunya pranata hukum yang tepat digunakan adalah hukuman badan, seperti potong tangan, rajam, cambuk dan lain sebagainya.

40 Sutrisno, Fazlur Rahman; Kajian terhadap Metode, Epistemologi dan Sistem Pendidikan, (Yogyakarta: Pustaka Pelajar, 2006), hal. 41-42.

${ }^{41}$ Muhammad Abid al-Jabiri, Bunyat al-'Aql al- 'Araby...op. cit., hal. 261, 271 dan 275.

${ }^{42}$ Sutrisno, Fazlur Rahman; Kajian terhadap Metode, Epistemologi dan Sistem Pendidikan, op.cit., hal. 43-44.

${ }^{43}$ Wardani, Epistemologi Kalam Abad Pertengahan (Yogyakarta: LKiS, 2003) Hal. 38. 
Dalam kasus potong tangan bagi pencuri, dalam analisis al-Jabiri karena dua alasan: pertama, bahwa hukum potong tangan terhadap pencuri telah diberlakukan sebelum Islam datang di semenanjung Arabia.

Kedua, dalam masyarakat Badawi (nomadik), penduduknya berpindah-pindah dari satu tempat ke tempat lainnya beserta tenda dan onta mereka dalam rangka mencari oase subur, maka tidak mungkin pada saat itu menghukum seorang pencuri dengan penjara atau hukuman lainnya. Sebab, pada saat itu dinding-dinding bangunan tidak banyak dijumpai ditambah tidak terdapat pemerintahan (penguasa) yang menjaga untuk memberi makan dan minum bagi orang yang dipenjara. ${ }^{44}$

Dilihat lebih jauh, secara struktural, Philip K. Hitti kemudian membagi masyarakat Arab pra-Islam menjadi tiga bentuk yaitu: Pertama, masyarakat komunal ('ashabiyyah) yang direpresentasikan dengan perang antar suku yang kerap terjadi.

Dalam masyarakat yang primitif semacam ini, tidak ada hukum yang diterapkan selain pembalasan yang setimpal, darah harus dibalas dengan darah. Oleh Islam praktik semacam ini mulai dihapuskan dengan cara mempersaudarakan antar suku dan persaudaraan berdasarkan keimanan.

Kedua, masyarakat pagan, penyembah berhala. Berhala ditumpuk di sekitar Ka'bah sebagai tuhan-tuhan kecil yang mereka sembah. Pada saat Islam datang, praktik penyembahan semacam ini mulai dihapuskan.

Ketiga, masyarakat patriarkhi. Artinya, masyarakat Arab adalah sekelompok orang yang lebih mengunggulkan laki-laki ketimbang perempuan. Oleh Islam, perempuan mulai diberi kehormatan dengan menanamkan prinsip persamaan dan perempuan mendapatkan warisan kendati separoh laki-laki, namun pada saat itu, ini merupakan kemajuan luar biasa. ${ }^{45}$

Uraian di atas sejatinya menegaskan bahwa Al-Qur'an sejatinya merupakan respon aktual bumi Arab saat itu. Hal ini diakui Umar ibn Khattab sendiri, sebagaimana dikutip Khalil Abdul Karim, mengatakan bahwa Arab adalah bahan baku Islam.

Artinya, tradisi pra-Islam ini telah banyak diadopsi dan kemudian diintegrasikan menjadi bagian dari Islam baik yang terkait dengan ritus, sosial kemasyarakatan, politik, ekonomi, hukum dan sebagainya. Dalam hal yang menyangkut ritual keagamaan, misalnya pelaksanaan ibadah haji, umrah, pengagungan terhadap Ka'bah, kesucian bulan-bulan haram

${ }^{44}$ Muhammad Abid al-Jabiri, Formasi Nalar Arab: Kritik Tradisi Menuju Pembebasan dan Pluralisme Wacana Interriligius, terj. Imam Khoiri dari kitab "Takwin al-'Aql al-'Arabi” (Yogyakarta: IRCisoD, 2003) hal. 165 .

${ }^{45}$ Philip K. Hitti, History of the Arab; From the Earliest Times to the Present (New York: Paldrave MacMillan, 2002), hal. 112-140. 
dan pertemuan umum pada hari Jumat, merupakan contoh-contoh ritus pra-Islam yang kemudian diadopsi oleh Islam setelah dilakukan modifikasi melalui ijtihad Nabi maupun wahyu Al-Qur'an. ${ }^{46}$

Selain itu, elaborasi di atas juga telah membuktikan bahwa dalam hukum Islam mempunyai karakter dinamis (adaptable) terhadap kebutuhan sosial, norma, tradisi dan lainnya. Hukum Islam berkarakterkan dinamis dan fleksibel terhadap perubahan-perubahan sepanjang masih dalam bingkai maqāshid al-syari'ah, yaitu untuk merealisasikan kemaslahatan umum.

Tidak mengherankan jika para ulama ushūliyyun -khususnya-- dari madzhab Hanafi mengemukakan kaidah (legal maxim) yang berbunyi: "taghayyur al-ahkkām bi taghayyuri alazminah wa al-amkinah" (perubahan hukum-hukum karena adanya perubahan-perubahan zaman dan tempat).

Kata "ruang dan waktu" dalam kaidah ini dipahami dalam arti luas sebagai konteks sosial yang mencakup segala aspek kehidupan. ${ }^{47}$

Disamping itu, yang tidak kalah penting adalah entitas bernama keberadaan (syari'ah) hukum Islam di Nusantara. Menelusuri tentang perkembangan hukum Islam lebih lanjut, sebenarnya pemikiran hukum Islam yang berkembang pada abad 17 dan $18 \mathrm{M}$, berada pada koridor keseimbangan antara tasawuf dan fikih.

Model karya hukumnya lebih merupakan anotasi dari karya ulama klasik dalam berbagai bentuknya seperti ta'liq (komentar), syarh (penjabaran), ikhtishar (ringkasan) walaupun ada beberapa ulama yang sudah mengembangkan nuansa khas dan unik seperti Hamzah Fanzuri, Nuruddin ar-Raniri, Syamsuddin as-Sumatrani, Abdul Ro'uf as-Singkili, dan sebagainya.

Karya-karya yang muncul mendasarkan pada pola fikih bermadzhab qauly (tekstualis) dan manhaji (metodologis) dalam satu aras madzhab Syafi'i.

Pada abad 19 M bisa dikatakan sebagai lanjutan dari proyeksi model pemikiran abad sebelumnya. Dalam abad ini muncul banyak tokoh diantaranya adalah Kiai Shaleh Darat.

Pada abad ini ada pergeseran pusat pemikiran Islam dari luar jawa (Sumatera dan Kalimantan) ke daerah Jawa. Dari segi corak dan metode pemikiran tidak ada

${ }^{46}$ Khalil Abdul Karim, op. cit., hal. 1.

47 Terkait kaidah ini lihat Muhammad ibn Ahmad al-Sharakhsi, al-Mabsut, Vol. 15 (Cairo: Mathba'ah alSa'adah, 1906) hal. 171, Jalal al-Din al-Suyuti, al-Asybah wa al-Naza 'ir (Cairo: Isa al-Babi al-Halabi, t.th.) hal. 99; Ibn Qayyim al-Jawziyah, I'lam al-Muwaqqi'in 'an Rabb al-'Alamin, Vol. 3 (Cairo: Mathba'ah al-Sa'adah, t.th.), hal. 14-66. 
perubahan besar, masih dengan pola bermadzhab dengan corak "syariah cum sufistik". 48

Dalam bahasa metaforis, relasi syari'at, tarekat, dan hakikat dapat diibaratkan dalam relasi antara kapal, samudra, dan intan. Dalam konteks ini, syariat merupakan kapalnya, sementara tarikat adalah samudranya, dan intan yang berada di dasar samudera menunjuk pada hakikat. Di sini pelaku sufi diibaratkan menjadi orang yang menaiki kapal dengan maksud hendak mengais atau mengambil intan di dasar samudera tersebut. ${ }^{49}$

Pada masa Kiai Shaleh Darat, perkembangan mistik Islam kejawen yang sarat dengan tasawwuf falsafi yang dilakukan masyarakat non-santri di jawa. Upaya mendialogkan tasawuf sunni ortodoks abad pertengahan dengan konteks lokal Muslim Jawa melalui bahasa Jawa.

Namun pada kenyataannya proses dialog antara teks dan konteks lebih mengedepankan teks sebagai pemilik otoritas kebenaran dari pada unsur-unsur lokalitas sehingga pemikiran tasawuf Saleh Darat cenderung kritis dan menolak lokalitas tersebut. ${ }^{50}$

Masyarakat muslim di Jawa tidak bisa dilepaskan keberadaannya dari Islam kebatinan, Islam Kejawen atau Islam Jawa. ${ }^{51}$ Keberadaan Islam Kejawen sudah menjadi bagian dari identitas muslim Jawa sejak Islam belum memasuki wilayah-wilayah pesisir di Jawa.

Keberadaan Islam kebatinan semakin menemukan bentuknya di tengah-tengah masyarakat, setelah mendapat dukungan penuh dari penguasa kerajaan Mataram, terutama pada era pemerintahan Sultan Agung pada pertengahan abad ke-17 M.

Islam kebatinan menunjuk pada perpaduan antara tradisi Jawa dengan unsur-unsur ajaran Islam, terutama aspek-aspek tasawwuf dan budi luhur yang terdapat dalam perbendaharaan kitab-kitab tasawwuf.

Sebagaimana yang terungkap dalam kepustakaan Islam Kejawen, kehadirannya sangat sedikit mengungkapkan aspek syariat dan bahkan sebagian ada yang kurang menghargai syariat sebagai aturan-aturan formal yang mengikat seluruh muslim di Nusantara, terutama Jawa. $^{52}$

${ }^{48}$ M. Ikhsanudin, "Mengembangkan Metodologi Penemuan Hukum Islam Syariah Cum Reality Studi Perspektif Historis dan Metodologis, dalam al-Mawarid, Vol. XII, No. 1, Feb-Agust 2012, hal. 121

${ }^{49}$ Saleh Darat, Majmu'ah ash-Shari'ah al-Kafiyah li al-Awam (Semarang: Toha Putra, 1348 H) hal. 27

${ }^{50}$ Ibid.

${ }^{51}$ Niels Mulder, Mistisisme Jawa dan Ideologi di Indonesia (Yogyakarta: LKiS, 2007), hal. 13

${ }_{52}$ Simuh, Mistik Islam Kejawen Raden Ngabehi Ronggowarsito, Suatu Studi terhadap Serat Wirid Hidayat Jati (Jakarta: Universitas Indonesia, 1988), hal. 2 
Islam masuk Nusantara abad ke-13 merupakan Islam sufi yang disebarkan oleh para guru tarekat. Melalui aktifvtas dakwah mereka, transformasi nilai-nilai Islam di Nusantara tetap menjiwai nilai-nilai kebudayaan atau unsur-unsur lama. Mereka menggunakan pendekatan akomodatif dan kompromistis dengan tidak mempersoalkan kemurnian agama. Maka, Islam dapat diterima dan berdampingan tradisi lama tanpa menimbulkan ketegangan yang berarti.

Berbagai institusi tradisi lama seperti kenduri dan ritual-ritual keagamaan lainnya dapat diislamkan dan mereka dapat menyusupkan unsur-unsur Islam tanpa mengorbankan filsafat dan seni kejawen mereka. ${ }^{53}$

Proses Islamisasi yang berlangsung secara harmonis, sesuai dengan kedudukan dan fungsi masing-masing keduanya sesungguhnya memainkan peran strategisnya baik dalam proses penyebaran dan pengembangan (modes of transfer) maupun dalam proses pembumian Islam (modes of translation and transmission) di wilayah Nusantara.

Pertama, menyangkut masalah tentang bagaimana Islam disebarluaskan dari satu tempat ke tempat lainnya, sementara yang kedua menyangkut tentang bagaimana proses pembelajaran (learning process) ajaran Islam bisar disemaikan, ditanam, dibuahkan dan diaktualisasikan (domestification process) dalam jiwa para pemeluknya, sesuai dengan latar sejarah dan lingkungan sosial budaya masyarakat pendukungnya.

Namun kemenangan gaung ortodoksi Imam al-Ghazali mengakibatkan dominasi kehidupan sufi yang merupakan refleksi tahap akhir kehidupan al-Ghazali begitu berpengaruh di dunia Sunni.

Sumbangan sufisme dari al-Ghazali yang telah dipadukan itu, secara resmi diterima oleh kaum syari'ah dengan semua unsur orde emosional yang telah menghidupinya. ${ }^{54}$ Demikian juga dari anjuran untuk berguru dalam bertasawwuf sehingga menimbulkan aliranaliran tarekat atau orde-orde sufi, ${ }^{55}$ yang mana lama-kelamaan semakin menyimpang dari apa yang dikehendaki al-Ghazali sendiri.

Penyimpangan ini terjadi karena tarekat-tarekat ini banyak dilakukan orang awam di daerah-daerah karena terpengaruh budaya lokal, sedangkan yang cabang-cabangnya ada diperkotaan relative masih dekat dengan ajaran resmi. hal. 22

${ }^{53}$ Simuh, Sufisme Jawa, Transformasi Tasawwuf Islam ke Mistik Jawa (Yogyakarta: Bentang, 2002),

${ }^{54}$ N.J.G. Kaptein (red), Pandangan Barat terhadap Literatur, Hukum, Filosofi, Teologi dan Mistik Tradisi Islam (Jakarta:INIS, 1988), hal. 97

${ }^{55}$ Ibid., hal. 67 
Regionalitas sufisme ini bertepatan dengan periode di mana ilmu pengetahuan agama dan seluruh kebudayaan Arab-Islam itu sendiri menjadi membeku. ${ }^{56}$

Di samping itu, penyebaran Islam di Nusantara telah mengalami dua proses sekaligus, yaitu: (1) proses adopsi (to adopt) elemen-elemen kultur Nusantara; dan (2) pada saat yang sama terjadi proses seleksi atau adaptasi (to adapt) kultur luar dengan nilai-nilai kultur internal. ${ }^{57}$

Pada akhir abad ke-16 M di berbagai wilayah Nusantara telah terjadi proses pembahasa lokalan (vernakularisasi) keilmuan Islam. Hal ini bisa dilihat dalam tiga fenomena. Pertama, digunakannya aksara arab dengan bahasa Melayu yang disebut dengan aksara Jawi.

Kedua, banyaknya kata serapan dari bahasa Arab yang telah ditransformasikan dalam bahasa lokal. Ketiga, banyaknya karya sastra yang terinspirasi oleh model-model karya sastra Arab. ${ }^{58}$

Corak Islam yang ortodoks sangat berkembang di wilayah pesisir Utara Jawa melalui pesantren-pesantren sebagai tempat persemaian karya-karya tulis keagamaan dan kesastraan. ${ }^{59}$ Yang mengimbangi wilayah Jawa pedalaman melalui Keraton sebagai pusatnya. ${ }^{60}$

Dalam teks-teks Islam Jawa Pesisiran, pengaruh budaya Islam sangatlah kuat. Islam mencapai Jawa melalui karya-karya tulis Islam Melayu. Akibatnya teks-teks Jawa Pesisiran isinya banyak meminjam dari teks-teks Islam berbahasa Melayu dan dari teks-teks berbahasa Arab. ${ }^{61}$

Bahasa Jawa Pesisiran yang awalnya merupakan tuturan ragam lisan/dialek pesisir Jawa yang melalui proses Islamisasi kemudian diadopsi sebagai bahasa Jawa Pesantren; dan berasal dari bahasa Jawa Pesantren ragam tulis itulah bahasa Jawa-Kitabi mempunyai posisi penting. Maka sebagai salah satu ragam Bahasa Jawa, Bahasa Jawa-Kitabi yang notabene merupakan bahasa keilmuan di Pesantren, sistem penulisannya selalu diekspresikan dengan menggunakan aksara pegon. ${ }^{62}$

Aksara pegon yang digunakan di Pesantren Jawa sebagai aksara akademik memang sebenarnya menjadi karakteristik aksara pesisiran. Sebab di daerah pesisiran pulau Jawa

\footnotetext{
${ }^{56}$ Ibid., hal. 68

${ }^{57}$ Erni Budiwanti, Islam Sasak: Wetu Telu Versus Wektu Lima (Yogyakarta: LKiS, 2001), hal.

58 Anthony H. Jhons, "Qur'anic Exegesis in The Malay World” dalam Andrew Rippin (ed), Approach to the History of the Interpretation of the Qur'an (Oxford: Clarendon Press, 1988), hal. 87-257

59 Muhammad Damami, "Pesantren”. Dalam Sastra Jawa: Suatu Tinjauan Umum. Edi Sedyawati (ed). Jakarta: Pusat Bahasa dan Balai Pustaka, 2001

60 Th. Piqeaud, Literature of Java (S-Gravenhage: Martinus Nijhoff, 1967), vol. 1, hal. 34

${ }^{61}$ Th. Piqeaud, Literature of Java, hal. 6

${ }^{62}$ Ibid., hal. 34
} 
inilah muncul pusat-pusat keislaman seperti pondok pesantren yang berfungsi sebagai tempat pendidikan agama Islam. Di tempat seperti itulah lahir peradaban baru di Jawa; (1) aksara pesantren Jawa yang disebut pegon, (2) bahasa Jawa-Islam yang disebut bahasa JawaKitabi, (3) teks-teks keagamaan Islam atau kesusasteraan Islam yang disebut sastra Pesantren. ${ }^{63}$

Islamisasi yang dilakukan oleh Kiai Saleh Darat dengan menggunakan nalar Islam pesisiran yang inklusif atau cenderung membuka cakrawala dialog dengan budaya setempat dapat ditemukan dalam kitab Majmu' al-Syari'ah al-Kafiyah li al-Awam. Beliau meresepsi kearifan lokal dengan mengatakan bahwa:

"Utawi kufur hiyo wong podo gawe shodaqoh bumi nejo hurmat danyang deso kono iku haram balik lamun niqodake ulihe hurmat marang danyang kerono danyang ingkang ngerekso deso kene lan kang aweh manfaat maring wong deso kene lan kang mbahu rekso sawah-sawah, utowo liyane mongko lamun mengkono i'tiqode mongko kufur kerono wajib ingatase mukallaf niqodaken setuhune makhluk kabeh iku apes ora biso gawe opo-opo yen ora kelawan qudroh lan irodahe Allah. Lamun sodaqoh wong iku iyo kang lillahi ta'ala ojo kerono hormat danyang"

(Menjadi kafir jika seseorang melakukan sedekah atau berbagi kepada orang lain dengan model sedekah bumi tapi dengan niat/tujuan memberikan penghormatan kepada Danyang yang diyakini memberikan manfaat kepada masyarakat. Pemberian status kekufuran tersebut didasarkan pada pertimbangan bahwa orang mukallaf wajib mempunyai keyakinan ketidakberdayaan makhluk kecuali dengan qudroh dan irodah Allah. Jika orang tersebut bersedekah, maka diharapkan hanya mempunyai niat kepada Allah bukan karena menghormati danyang). ${ }^{64}$

Berpijak dari teks tersebut, sebenarnya beliau menekankan bahwa sedekah sebagai jaring pengaman sosial umat Islam merupakan salah satu ajaran yang harus dikerjakan dan dilestarikan namun harus dengan niatan yang bagus. Karena dalam literatur fikih syafi'iyah, niat dalam ibadah itu menempati posisi yang sentral karena terkait dengan legalitas ibadah tersebut. Beliau tidak bisa melepaskan nalar Islam pesisiran yang selalu membuka ruang dialog antara Islam dan keyakinan masyarakat lokal.

Dalam persoalan keyakinan yang bersifat tetap (tsabit), beliau tidak langsung menghakimi praktek sedekah bumi yang dilakukan masyarakat Jawa yang diorientasikan

${ }^{63}$ R.M.Ng Poerbatjaraka dan Tardjan Hadiwijaya, Kepustakaan Djawa (Kolff Jakarta: Djambatan, 1950), hal. 75

${ }^{64}$ Saleh Darat, Majmu'ah ash-Shari'ah al-Kafiyah li al-Awam, hal. 24 


\section{Dr. Nurul Huda, M.HI}

untuk menghormati Danyang/makhluk halus yang diyakini dapat memberi manfaat dan madharat bagi masyarakat. Memang, praktek dengan niatan tersebut bertentangan dengan ajaran Islam karena tidak ada yang dapat memberikan manfaat dan madharat kepada manusia kecuali Allah semata, namun begitu, beliau justru memberikan solusi alternatif sekaligus ruang dialog dengan masyarakat setempat untuk melakukan sedekah/merancang tradisi yang tidak bertentangan dengan ajaran Islam (diniatkan hanya kepada Allah semata). Dengan begitu, tradisi masyarakat dapat dirawat dan dilanjutkan dengan leluasa karena masih dalam koridor Islam.

Uraian di atas memberikan penjelasan bahwa dalam persoalan keyakinan, indikator pertentangan ajaran Islam dikembalikan pada substansi keyakinan yang tertanam dalam hati yang berupa niat, bukan pada bentuk praktek tradisinya.

Dengan demikian, semua orang Islam dapat merancang tradisi keagamaan dengan bebas yang disesuaikan dengan konteksnya, asalkan niat/motivasi tradisi tersebut masih diorientasikan kepada Allah bukan lainnya.

Prinsip tersebut membawa konsekuensi lanjutan bahwa dakwah Islam tidak harus diobsesikan untuk merubah tradisi yang secara formal tidak dikenal di dunia Arab melainkan harus diorientasikan untuk merubah niat/motivasi yang bertentangan dengan ajaran Islam karena substansi ibadah bertumpu pada niat/motivasi seseorang sekaligus menjadi unsur pembeda antara ibadah dan tradisi.

Beliau juga tidak luput mengomentari penetapan hari pernikahan dengan petunjuk dukun sebagai berikut:

"Lan ora wenang nggugu pangucape wong ahli nujum lan pangucape dukun iki dina atawa sasi ora bagus ginawe akad nikah lan ora wenang nganggo itungan wetone lanang lan wadon kerono iku itungan jahiliyah lan ora wenang haram nggugu pangucape kahin tukang itung kelawan pon keliwon iku kabeh goroh ora ono wetone sangkeng al-Qur'an lan ora ono wetone sangkeng hadits".

(Dan tidak boleh mempercayai ucapan ahli perbintangan dan ucapan seorang dukun terkait hari dan bulan yang bagus untuk dibuat akad nikah dan hitungan weton lelaki dan perempuan karena itu hitungan jahiliyah, dan tidak boleh percaya terhadap kahin/tukang hitung berdasarkan pasaran pon kliwon. Semua itu bohong, tidak ada dalam al-Qur'an dan Sunnah). ${ }^{65}$

${ }^{65}$ Saleh Darat, Majmu'ah ash-Shari'ah al-Kafiyah li al-Awam, hal.211-212. 
Dari teks tersebut, kelihatannya Kiai Saleh Darat sangat bersemangat untuk menghakimi tradisi pernikahan yang dikaitkan dengan hitungan weton dan pasaran sebagai tradisi jahiliyah dan tidak bersumber dari al-Qur'an dan Sunnah.

Namun kalau diteliti lebih lanjut, tentu persepsi beliau tidak dapat dilepaskan dari prinsip dialogis dan teori niat dalam persoalan ibadah/keyakinan. Yakni mempercayai dukun/ahli nujum yang dapat mendatangkan manfaat dan madharat dalam pernikahan tentu perbuatan jahiliyah dan tidak ada dalam al-Qur'an dan Sunnah, namun kalau pernikahan dilaksanakan dengan menggunakan hitungan weton dan pasaran dan berdasarkan niat yang hanya diorientasikan kepada Allah semata, tentu tidak jadi masalah karena orang tersebut hanya percaya bahwa yang dapat memberi manfaat dan madharat hanya Allah semata.

"Engkang tetep gawe walimah iku lanang ora wadon moko gawe walimah sakkuwasane lan ora wenang kelawan merdi-merdi barangkang ora maujud lan ora wenang kelawan utang-utang kerono cukup walimah kelawan tamar saklas. Anapun ghalibe wong awam podo gawe walimah kelawan ujub, riya, sum'ah moko haram ora wenang nekani khususon kelawan utang-utang lan kelawan merdi-merdi”.

(Secara etika, yang membuat walimah pernikahan adalah pihak lelaki bukan perempuan. Pihak lelaki membuat walimah sesuai dengan kekuatannya, tidak boleh memaksakan kehendak sampai berhutang karena walimah cukup dengan suguhan kurma satu las. Jika pada umumnya masyarakat membuat walimah dengan motivasi membanggakan diri, memamerkan harta terlebih lagi dengan berhutang, maka haram mendatangi pernikahan tersebut). ${ }^{66}$

Berpijak dari teks di atas, Kiai Saleh Darat juga mengomentari tradisi walimah pernikahan yang sebenarnya diluar kemampuan masyarakat dengan motivasi membanggakan diri dan memamerkan diri. Prinsip dialogis digunakan beliau dalam mengomentari persoalan tersebut. Yakni beliau tidak langsung mengharamkan mendatangi walimah namun beliau menunjukkan alasan larangan tersebut yang bertumpu pada motivasi yang keliru dan takalluf yang dilarang dalam ajaran tasawuf Islam.

Dengan demikian, masyarakat Jawa dapat berdialog dengan dirinya sendiri; dalam arti jika walimah dilaksanakan tanpa motivasi keliru dan sesuai dengan kemampuannya, maka tradisi tersebut tentu tidak bermasalah.

Integrasi fikih dengan tasawuf juga dapat ditemukan dalam kitab Manasik Haji dan Umroh sebagai berikut:

${ }^{66}$ Saleh Darat, Majmu'ah ash-Shari'ah al-Kafiyah li al-Awam, hal. 231. 
"Moko nuli istilamo siro marang hajar aswad moko niqodno siro setuhune istilam lan nyисир hajar aswad iku gawe biat kelawan Allah tegese ngalap janji kelawan Allah yen temen-temen saguh ngelakoni perintah lan ngedohe sekabehane cegah, moko seng sopo wonge wus towaf moko nuli ngelakoni maksiat utowo tinggal fardhu moko iku sasat ngerusak janjine dewe kelawan Allah, moko ikulah engkang diarani wong fasek”.

(ketika seseorang istilam dan mencium Hajar Aswad, maka ia harus meyakini bahwa proses tersebut merupakan baiat atau perjanjian dengan Allah SWT untuk benar-benar menyanggupi pelaksanaan perintah dan pencegahan dari semua larangan.

Maka siapa saja yang sudah melakukan ibadah thowaf kemudian masih melakukan kemaksiatan atau meninggalkan kewajiban, maka orang tadi dianggap merusak perjanjian dengan Allah dan masuk dalam katagori orang yang fasik). ${ }^{67}$

Sedangkan integrasi nalar bayani dan irfani dapat ditemukan di karya lain Kiai Saleh Darat sebagai berikut:

“Utawi syarat kaping pindo iku arep ngerekso lisane sangkeng ngumyang dongeng tanpo faedah lan ngerekso lisane sangkeng goroh lan ngerasani lan caturan utowo lalan padu tukar moko wajib wongkang puoso iku meneng anteng anggotane kabeh serto ketungkul atine kelawan dzikir lan moco qur'an moko mengkono ikulah puasane lisan. Lamun ora kuoso mengkono moko wajib siro turuo bahe kerono pangendikane kanjeng nabi utawi turune wong kang poso iku ibadah lan angendikane imam Sufyan utawi ngerasani iku ngerusaaken puasane kerono ngerasani kuwi hukume wus mangan daging mentah kerono pangendikane Allah SWT “ayuhibbu ahadukum an ya'kula lahma akhihi”.

(adapun syarat puasa yang kedua adalah menjaga lidah dari cerita yang tidak berguna, berbohong, menggunjing, dan saling marah, dan seluruh anggota badan serta selalu dzikir/ingat kepada Allah dan membaca al-Qur'an. Namun jika seseorang tadi tidak mampu, diwajibkan untuk tidur karena menurut Nabi, tidur itu ibadah sedangkan menurut imam Sufyan menggunjing itu dapat merusak puasa karena sudah dianggap makan daging mentah seperti tertera dalam al-Qur'an). ${ }^{68}$

Dalam kesempatan lain, Kiai Saleh Darat juga mengomentari tradisi orang Arab yang membuat standarisasi kesebandingan dalam pernikahan (kafa'ah) berdasarkan suku seperti keturunan bani Hasyim dan bani Muthalib tidak sebanding dengan selainnya karena mereka

${ }^{67}$ Saleh Darat, Kitab Manasik al-Haj Wa al-Umroh Wa Adab al-Ziyaroh Li Sayyid al-Mursalin (tt: AlKarimi, tth) hal. 66-67.

${ }^{68}$ Saleh Darat, Kitab Lathoif al-Thoharoh Wa Asror al-Sholat Fi Kayfiyati Sholat al-Abidin Wa al-Arifin Tsuma Yalihi Kitab Asror al-Shiyam Tsumma Kitabu Fadhilati al-Muharromi Wa Rojaba Wa Sya'bana (Semarang: Karya Toha Putra, tth) hal. 59-60. 
adalah keturunan mulia atau bangsawan dari kalangan Arab. Kiai Saleh Darat juga merawat tradisi kebangsawanan sebagai berikut:

"Endi-endi wongkang mulyo nasabe iyo ora ngufoni ing wongkang asor nasabe contone anak lanange wongkang ora tedak raden iku ora ngufoni ing anak wadone wong kang tedak raden kerono raden iku nasab mulyo munggoh ajam Jowo"

(Setiap orang keturunan mulia tidak seimbang (tidak kufu) dengan orang yang keturunannya rendah misalnya anak lelaki yang lahir tidak dari Raden itu tidak sebanding (tidak kufu) dengan perempuan yang lahir dari keturunan Raden karena Raden itu keturunan mulia menurut orang Jawa). ${ }^{69}$

Dari keterangan di atas, Kiai Saleh Darat juga ingin memperkenalkan bahwa tradisi sistem kekerabatan berdasarkan keturunan mulia/bangsawan juga terjadi dalam masyarakat Jawa. Orang keturunan bangsawan tidak sebanding dengan orang yang tidak bangsawan, maka, beliau secara bebas menambah ketentuan kafa'ah dengan mengadopsi sistem kekerabatan yang berlaku pada masyarakat Jawa.

Dengan demikian, beliau mencoba mentransformasikan interrelasi tradisi pemikiran yang bertingkat; 1) tradisi pemikiran Jawa, 2) tradisi pemikiran Islam-Jawa; 3) tradisi pemikiran Islam-Arab yang ketiganya berjalinkelindan tatkala terjadi transformasi ilmu pengetahuan.

Kandungan kitab ini kalau dihubungkan dengan konteks perkembangan Islam di Jawa pada abad ke-19, maka dapat disimpulkan bahwa kandungan kitab sesuai dengan perkembangan Islam di Jawa yang sedang mengalami Islamisasi yang kuat. Namun metode yang ditempuh sangat berbeda dengan perkembangan Islam di tingkat Internasional pada waktu itu, yakni sedang terjadinya kebangkitan Islam yang hanya bertumpu pada al-Qur'an dan Sunnah.

Secara epistemik, proyek islamisasi yang dilakukan oleh Kiai Saleh Darat tidak terjangkiti empat elemen pokok; pertama, subyektifitas yang reflektif, yaitu pengakuan akan kekuatan-kekuatan rasional dalam memecahkan masalah-masalah kehidupan; kedua, subyektifitas berkaitan dengan kritik atau "refleksi", yaitu kemampuan untuk menyingkirkan kendala-kendala kebebasan dari tradisi dan sejarah; ketiga, kesadaran historis yang dimunculkan oleh subyek; keempat, universalisme dalm arti elemen-elemen tersebut bersifat normatif untuk segala masyarakat yang mau melangsungkan Islamisasi; keempat totalitarianisme, menjadi Muslim harus menyetujui asas tunggal, dan abadi sehingga

\footnotetext{
${ }^{69}$ Saleh Darat, Majmu'ah ash-Shari'ah al-Kafiyah li al-Awam, hal. 220
} 


\section{Dr. Nurul Huda, M.HI}

berpotensi menghakimi dan menghilangkan pluralitas budaya lokal yang bersifat incommensurable.

Implikasi selanjutnya Kiai Saleh Darat telah mendudukkan secara pararel antara tradisi Arab dan tradisi lokal sebagai sebuah entitas yang saling menggeluti pemaknaan hidup, sehingga memungkinkan dialektika antara tradisi dan melahirkan tradisi baru. Telah melakukan pendekatan praktis yang didasarkan pada kebudayaan bukan sekumpulan sesuatu yang harus diterima dan dilestarikan, melainkan merupakan sesuatu yang dibentuk, suatu konstruksi sosial yang berkaitan erat dengan kepentingan dan kekuasaan yang sedang berjalan.

Pendekatan ini berimplikasi pada adanya hubungan saling membentuk, saling belajar, dan saling mengambil sebagai hubungan dialektis antara subyek dan struktur objektif. Dan pendekatan wacana yang berasumsi perlunya penciptaan ruang tempat tumbuh suburnya wacana tentang kebudayaan sebagai hasil negosiasi konstruktif yang terus berkembang. Dan memprioritaskan invensi dan inovasi sebagai upaya menemukan, meratifikasi, merekonsiliasi, mengkomunikasikan, menganyam dan menghasilkan konstruksi-konstruksi baru.

Memang, Kiai Saleh Darat mendasarkan seluruh pemikirannya kepada teks-teks dan naskah-naskah keagamaan yang disusun dan dikarang oleh para fuqaha', mutakallimun, mufassirun dan para tokoh sufi pada suatu abad dan kondisi sosial tertentu.

Namun demikian, formulasi dan konsepsi tersebut tidak diandaikan memiliki sifat yang universal dan mutlak, yang mewakili high tradition. Karena berimplikasi pada pencampuran dan ketertumpangtindihan antara dimensi historisitas yang berubah-ubah dan normativitas yang tidak tidak bisa berubah yang sesuai pada tempat dan waktu. Padahal masyarakat muslim di seluruh dunia (pada khususnya Jawa) tidak seluruhnya dapat terwakili dalam budaya high tradition.

Sejatinya Kiai Saleh Darat menyeponsori low tradition yang menfokuskan aspek perilaku dan pergumulan masyarakat muslim dalam kehidupan mereka sehari-hari baik secara ritual maupun personal. Sehingga Islam dapat didekati dengan kajian historis-empiris yang pada gilirannya akan menampakkan wajah Islam bukan legal-formal namun Islam yang kaya nuansa, multidimensional, warna-warni sosiokulturalnya. ${ }^{70}$

\section{PENUTUP}

${ }^{70}$ Amin Abdullah, dkk, Restrukturisasi Metodologi Islamic Studies Mazhab Yogyakarta (Yogyakarta: SUKA Press, 2007), hal. 11-13 
Formasi nalar fikih Kiai Saleh Darat mengambil corak nalar fikih Islam pesisir bayani cum irfani yang bersifat, pertama, dialektis; konstruksi nalar yang mengakui perlunya dialektika antara tradisi Arab dan tradisi lokal sebagai sebuah entitas yang saling menggeluti pemaknaan hidup, sehingga melahirkan tradisi baru. Kedua, Semi-Partikularistik; nalar yang tidak mengakui elemen-elemen bersifat normatif secara mutlak untuk segala masyarakat yang mau melangsungkan Islamisasi. Ketiga, Semi-Pluralistik; konstruksi nalar yang tidak menyetujui asas tunggal dan abadi secara mutlak sehingga berpotensi menghakimi dan menghilangkan pluralitas budaya lokal yang bersifat incommensurable.

\section{DAFTAR PUSTAKA}

A'la, Abd. Jahiliyah Kontemporer dan Hegemoni Nalar kekerasan; Merajut Islam Indonesia Membangun Peradaban Dunia, Yogyakarta: LKiS, 2014.

Abdullah, Amin. dkk, Restrukturisasi Metodologi Islamic Studies Mazhab Yogyakarta, Yogyakarta: SUKA Press, 2007.

Abdullah, M. Amin. "al-Ta'wil al-'Ilmi: Ke Arah Paradigma Penafsiran Kitab Suci” dalam Jurnal al-Jami'ah Vol. 39, Number 2 July-December 2001.

Abdullah, M. Amin. "Rekonstruksi Metodologi Studi Agama dalam Masyarakat Multikultural dan Multirelijius" dalam M. Amin Abdullah, dkk (editor), Antologi Studi Islam; Teori dan Metodologi, Yogyakarta: Sunan Kalijaga Press, 2000.

Al-Anshari, Ibn Mandhur. Lisan al-Arab, Jilid XIII, Beirut: Dar al-Fikr, t.th. 
Al-Jabiri, Muhammad Abid. Bunyat al-'Aql al-'Araby: Dirasah Tahliliyah Naqdiyah li Nuzhumi al-Ma'rifah fi al-Tsaqafah al- 'Arabiyah, Beirut: Markaz Dirasat al-Wihdat al-'Arabiyah, Cet. Ke-3, 1990.

Al-Jabiri, Muhammad Abid. Formasi Nalar Arab; Kritik Tradisi Menuju Pembebasan dan Pluralisme Wacana Interreligius, terj. Imam Khoiri, Yogyakarta: IRCiCoD, 2003.

Al-Jabiri, Muhammad Abid. Post-Tradisionalisme Islam, terj. Ahmad Baso, Yogyakarta: LkiS, 2000.

Al-Jawziyah, Ibn Qayyim. I'lam al-Muwaqqi'in 'an Rabb al-'Alamin, Vol. 3, Cairo: Mathba'ah al-Sa'adah, t.th.

Al-Jurjani, Abu al-Hasan al-Husaini. al-Ta'rifāt, Mesir: Musthafa al-Babi al-Halabi, 1938.

Al-Qarâdhawî, Yusuf. al-Madkhal li Dirâsah al-Syarî'ah, Kairo: Maktabah Wahbah, 2001.

Al-Sharakhsi, Muhammad ibn Ahmad. al-Mabsut, Vol. 15, Cairo: Mathba'ah al-Sa'adah, 1906.

Al-Suyuti, Jalal al-Din. al-Asybah wa al-Naza 'ir, Cairo: Isa al-Babi al-Halabi, t.th.

Anwar, Syamsul. "Pengembangan Metode Penelitian Hukum Islam" dalam Ainurrofiq (ed.), Mazhab Jogja”; Menggagas Paradigma Ushul Fiqh Kontemporer, Yogyakarta: ArRuzz Press dan Fakultas Syariah IAIN Sunan Kalijaga, 2002.

Arkoun, Muhammad. al-Fikru al-Ushuly wa Istihalat at-Ta'sil Nahwa Tarikhin Akhar li alFikr al-Islamy, London: Dar as-Saqi, 1999.

Azizy, A. Qodri. Eklektisisme Hukum Nasional: Kompetisi antara Hukum Islam dan Hukum Umum, Yogyakarta: Gama Media, 2002.

Barton, Greg. Gagasan Islam Liberal di Indonesia, Jakarta: Paramadina, 1995.

Berger, Peter L. (ed), The Other Side of God: A Polarity in World Religions, Radius Institute, 1981.

Budiwanti, Erni. Islam Sasak: Wetu Telu Versus Wektu Lima, Yogyakarta: LKiS, 2001.

Coulson, Noel J. Conflicts and Tensions in Islamic Jurisprudence, Chicago: The University of Chicago Press, 1969.

Damami, Muhammad. "Pesantren”. Dalam Sastra Jawa: Suatu Tinjauan Umum. Sedyawati, Edi (ed). Jakarta: Pusat Bahasa dan Balai Pustaka, 2001.

Darat, Saleh Majmu'ah ash-Shari'ah al-Kafiyah li al-Awam, Semarang: Toha Putra, 1348 H.

Darat, Saleh. Kitab Lathoif al-Thoharoh Wa Asror al-Sholat Fi Kayfiyati Sholat al-Abidin Wa al-Arifin Tsuma Yalihi Kitab Asror al-Shiyam Tsumma Kitabu Fadhilati alMuharromi Wa Rojaba Wa Sya'bana, Semarang: Karya Toha Putra, tth. 
Darat, Saleh. Kitab Manasik al-Haj Wa al-Umroh Wa Adab al-Ziyaroh Li Sayyid alMursalin, tt: Al-Karimi, tth.

Fyzee, Asaf A.A. Outlines of Muhammadan Law, London: Oxford, 1960.

Hitti, Philip K. History of the Arab; From the Earliest Times to the Present, New York: Paldrave Mac-Millan, 2002.

Ikhsanudin, M. "Mengembangkan Metodologi Penemuan Hukum Islam Syariah Cum Reality Studi Perspektif Historis dan Metodologis, dalam al-Mawarid, Vol. XII, No. 1, FebAgust 2012.

Jhons, Anthony H. "Qur'anic Exegesis in The Malay World" dalam Andrew Rippin (ed), Approach to the History of the Interpretation of the Qur'an, Oxford: Clarendon Press, 1988.

Kaptein, N.J.G. (red), Pandangan Barat terhadap Literatur, Hukum, Filosofi, Teologi dan Mistik Tradisi Islam, Jakarta:INIS, 1988.

Lee, Robert D. Overcoming Tradition and Modernity: The Search for Islamic Authenticity, Westview Press, A Division of Harper Collins Publishers, Inc, 1997.

Mulder, Niels. Mistisisme Jawa dan Ideologi di Indonesia, Yogyakarta: LKiS, 2007.

Nusibeh, Sari. "Epistemology" dalam Oliver Leaman dan Sayyed Hossein Nasr (ed.), History of Islamic Philoshopy Part II, London and New York: Routledge, 1996.

Piqeaud, Th. Literature of Java, vol. 1, S-Gravenhage: Martinus Nijhoff, 1967.

Satria Effendi M, "Ijtihad Sepanjang Sejarah Hukum Islam: Memposisikan KH, Ali Yafie" dalam Jamal D. Rahman (ed.) Wacana Baru Fiqh Sosial; 70 Tahun KH Ali Yafie, Bandung: Mizan, 1997.

Simuh, Mistik Islam Kejawen Raden Ngabehi Ronggowarsito, Suatu Studi terhadap Serat Wirid Hidayat Jati, Jakarta: Universitas Indonesia, 1988.

Simuh, Sufisme Jawa, Transformasi Tasawwuf Islam ke Mistik Jawa, Yogyakarta: Bentang, 2002.

Sulaiman, Abd al-Wahhab Ibrahim Abi. al-Fikru al-Ushuli; Dirasah Tahliliyyah Naqdiyyah, Cet. I, Jeddah: Dar al-Syuruq, 1983.

Sutrisno, Fazlur Rahman; Kajian terhadap Metode, Epistemologi dan Sistem Pendidikan, Yogyakarta: Pustaka Pelajar, 2006.

Syam, Nur. Madzhab-Madzhab Antropologi, Yogyakarta: LKiS, 2011.

Syamsuddin, Sahiron. Upaya Integrasi Hermeneutika dalam Kajian Qur'an dan Hadis, Yogyakarta: Lembaga Penelitian UIN SUKA, 2011.

Syarifuddin, Amir. Pembaruan Pemikiran dalam Hukum Islam, Padang: Angkasa Raya, 1990. 
Tardjan Hadiwijaya, R.M.Ng Poerbatjaraka. Kepustakaan Djawa, Kolff Jakarta: Djambatan, 1950.

Umar, Nasaruddin. Argumen Keseteraan Jender: Perspektif Alquran, Jakarta: Paramadina, 1999.

Usman, Iskandar. Istihsan dan Pembaruan Hukum Islam, Jakarta: Rajawali Pers dan Lembaga Studi Islam dan Kemasyarakatan, 1994.

Wardani, Epistemologi Kalam Abad Pertengahan, Yogyakarta: LKiS, 2003.

Zahrah, Muhammad Abu. Ushul al-Fiqh, Kairo: Dar al-Fikr al-'Arabi, 1987.

Zaid, Nashr Hamid Abu. al-Tafkir fi Zamani al-Tafkir, Kairo: Sina’ li al-Nasyr, 1995. 